\title{
Penyuluhan Pentingnya Kemandirian Pangan Dan Gizi Seimbang Dalam Rumah Tangga Melalui Pemanfaatan Pekarangan Lahan Kering Di Desa Gumantar Lombok Utara
}

\author{
Bambang Budi Santoso*, Jayaputra, I Komang Damarjaya \\ Kelompok Peneliti Bidang Ilmu Pengembangan Pertanian Lahan Kering \\ Fakultas Pertanian UNRAM.
}

Article history

Received: 10-11-2021

Revised: 19-11-2021

Accepted: 27-11-2021

*Corresponding Author: Bambang Budi Santoso Kelompok Peneliti Bidang Ilmu Pengembangan Pertanian Lahan Kering Fakultas Pertanian Universitas Mataram, Jl. Majapahit No. 62, Mataram, Lombok-Nusa Tenggara Barat, Indonesia

Email:

bambang.bs@unram.ac.id

\begin{abstract}
Agricultural land in the Gumantar Village area is dry land with relatively low productivity and diversification of food production, which then causes low income and food availability for farming families, so that it could have an impact on unbalanced food consumption and nutrition for family members and could also threaten household food security. However, on the other hand, the average farmer household has a fairly large yard, but it has not been used optimally. Therefore, counseling was carried out to the community which aims to increase the knowledge and understanding of farmers on the understanding of balanced nutrition and at the same time use the yard around the house in realizing food independence and fulfilling the nutritional needs of the family. The extension activity was carried out in June 2021. This extension activity was considered successful, seen from the enthusiasm and perseverance of the participants in participating in the extension activity and then hoping for follow-up in the practice of using the yard. The farming community of Gumantar Village has high enthusiasm for the realization of the use of the yard as a source of nutritious food.
\end{abstract}

Keywords: diversification; horticulture; yard; utilization

Abtrak: Lahan pertanian di kawasan Desa Gumantar merupakan lahan kering dengan produktivitas dan diversifikasi produksi pangan relatif masih rendah, yang kemudian menyebabkan rendahnya pendapatan dan ketersediaan pangan keluarga petani, sehingga dapat berdampak pada konsumsi pangan dan gizi anggota keluarganya yang tidak seimbang serta dapat mengancam ketahanan pangan rumah tangga. Pada sisi lain, rata-rata rumah tangga petani memiliki pekarangan yang cukup luas, namun belum dimanfaatkan secara optimal. Oleh karena itu telah dilakukan penyuluhan kepada masyarakat yang bertujuan untuk meningkatkan pengetahuan dan pemahaman petani terhadap pemahaman gizi seimbang dan sekaligus pemanfaatan lahan pekarangan sekitar rumah dalama mewujudkan kemandirian pangan dan pemenuhan kebutuhan gizi keluarga. Kegiatan penyuluhan dilaksanakan pada bulan Juni 2021. Kegiatan penyuluhan ini dinilai berhasil dilihat dari antusiasme dan ketekunan peserta dalam mengikuti kegiatan penyuluhan dan kemudian berharap tindak lanjutnya dalam praktek pemanfaatan pekarangan. Masyarakat petani Desa Gumantar memiliki antusiasme tinggi untuk terwujudnya pemanfaatan pekarangan sebagai sumber pangan bergizi.

Kata Kunci: : diversifikasi; hortikultura; pekarangan; pemanfaatan 


\section{PENDAHULUAN}

Secara umum kondisi lahan pertanian di Desa Gumantar merupakan lahan kering dengan produktivitas dan diversifikasi produksi pangan yang dapat dihasilkan dari kegiatan usahatani masih tergolong relatif rendah. Kegiatan usahatani yang diterapkan masyarakat petani di desa ini masih bersifat tradisional dan tidak intensif serta belum berorientasi pasar. Kondisi ini tentunya akan berpengaruh jelek terhadap ketersediaan pangan dan tingkat pendapatan keluarga petani, yaitu relative masih pula.

Pada kondisi saat sekarang ini, pemahaman rumah tangga petani terhadap peranan berbagai jenis pangan sebagai sumber zat-zat gizi yang dibutuhkan tubuh untuk hidup sehat, seperti sayuran dan buah-buahan dan pangan lainnya masih sangat rendah. Keadaan ini tentu akan berpengaruh terhadap ketersediaan pangan bagi keluarga yang tidak beragam dan bergizi seimbang. Pada akhirnya nanti dapat mengakibatkan terjadinya gizi kurang dan dapat mengancam ketahanan pangan rumahtangga. Ketersediaan pangan dalam jumlah yang cukup dan beragam sepanjang waktu merupakan keniscayaan yang tidak terbantahkan (Kementan, 2011). Oleh karena itu, setiap rumah tangga diharapkan mengoptimalisasi sumberdaya yang dimiliki, termasuk pekarangan, dalam menyediakan pangan bagi keluarga.

Pekarangan merupakan agroekosistem yang sangat baik dan memiliki potensi yang besar dalam mencukupi kebutuhan hidup petani atau pemiliknya, bahkan kalau dikembangkan secara baik akan dapat bermanfaat lebih banyak lagi, seperti kesejahteraan masyarakat sekitar, dan pemenuhan kebutuhan pasar (Widyawati dan Rizal, 2015). Melalui optimalisasi pemanfaatan lahan pekarangan diharapkan dapat meningkatkan kemandirian pangan keluarga dari berbagai komoditas pangan yang dibutuhkan untuk memenuhi kebutuhan pangan dan gizi keluarga. Lahan pekarangan rumah merupakan salah satu potensi sumberdaya yang dimiliki rumahtangga yang dapat dimanfaatkan sebagai alternatif untuk mewujudkan ketahanan dan kemandirian pangan rumah tangga (Azhari et al., 2012).

Melalui konsep Rumah Pangan Lestari (RPL) dengan prinsip dasarnya bahwa (i) pemanfaatan pekarangan yang ramah lingkungan dan dirancang untuk ketahanan dan kemandirian pangan, (ii) diversifikasi pangan berbasis sumber daya lokal, (iii) konservasi sumberdaya genetik pangan dan (iv) menjaga kelestariannya melalui kebun bibit desa menuju (v) peningkatan pendapatan dan kesejahteraan masyarakat (Kementan, 2011). Tujuan penting kegiatan penyuluhan yang ingin dicapai melalui pemanfaatan konsep KRPL antara lain meningkatkan pengetahuan, pemahaman, dan kesadaran keluarga dan masyarakat dalam nantinya memanfaatkan lahan pekarangan, memenuhi kebutuhan pangan dan gizi keluarga dan masyarakat secara lestari, mengembangkan kegiatan ekonomi produktif keluarga serta menciptakan lingkungan hijau yang bersih dan sehat secara mandiri. Sementara itu, Kelompok Tani Lembah Telaga yang ada di Desa Gumantar merupakan kelompok tani yang relative maju dalam kaitannya bercocok tanam di lahan pertanian dan mudah untuk menerima masukan teknologi budidaya yang perlu dikembangkan (inovasi baru). Naskah ini menyajikan hasil kegiatan penyuluhan yang telah kami lakukan dengan tujuan meningkatkan pengetahuan dan pemahaman serta memicu awal antusiasme anggota rumah tangga petani lahan kering di Desa Gumantar khususnya dusun Amor-amor dalam memanfaatkan lahan pekarangan untuk mendukung kemandirian pangan dan konsumsi gizi seimbang serta manfaat ekonomis lainnya.

\section{METODE}

Kegiatan penyuluhan dalam rangka pengabdian kepada masyarakat ini telah dilaksanakan di Desa Gumantar Kecamatan Kayangan Kabupaten Lombok Utara. Peserta kegiatan adalah anggota Kelompok Tani Lembah Telaga sebanyak sekitar 20 orang. Penentuan peserta binaan ini dilakukan oleh 
ketua dan pengelola Kelompok Tani Lembah Telaga dan Tim PPM Kelompok Peneliti Pertanian Lahan Kering Fakultas Pertanian Universitas Mataram. Peseta binaan yang dipilih adalah anggota kelompok tani yang mempunyai motivasi untuk mengikuti kegiatan penyuluhan ini.

Kegiatan penyuluhan telah dilaksanakan dengan cara atau menggunakan metode ceramah disertai dengan presentasi menggunakan Power Point dan dikuti diskusi dan tanya jawab. Presentasi Power Point dimaksudkan untuk mempertegas maksud dari ceramah dan meberikan contoh-contoh teknik pengelolaan pekarangan yang sesuai dengan potensi sumberdaya setempat dengan menampilkan secara visual penerapan berbagai teknologi tepat guna dalam pengelolaan pekarangan yang telah ada di daerah-daerah lain, sebagai contoh kelak.

Evaluasi merupakan kegiatan akhir program pengabdian kepada masyarakat, berupa penyuluhan ini. Evaluasi dilakukan terhadap tingkat anthusiasme dan keterlibatan peserta, serta serapan peserta terhadap kegiatan penyuluhan yang telah dilakukan. Tanggapan peserta terhadap kegiatan penyuluhan ini dan keinginan untuk menerapakannya pada lahan pekarangan masing-masing rumah tangga petani menjadi tolok ukur utama keberhasilan kegiatan pengabdian kepada masyarakat yang berupa penyuluhan ini.

\section{HASIL DAN PEMBAHASAN}

\section{Tahap persiapan}

Tahap persiapan yang meliputi pendekatan- pendekatan dengan berbagai unsur dalam masyarakat seperti tokoh masyarakat, tokoh pemuda, kelompok tani dan pemerintahan desa khususnya perangkat Dusun Amor-amor.

Beberapa hal yang dilakukan pada tahap persiapan meliputi:

1. Observasi dan Sosialisasi program kegiatan kepada masyarakat. Kegiatan ini dilakukan untuk mengidentifikasi potensi wilayah dan penyamaan persepsi dengan berbagai unsur dalam masyarakat seperti tokoh masyarakat dan pemerintahan desa. Penyamaan persepsi ini berkaitan dengan potensi sumberdaya manusia dan potensi sumberdaya setempat yang dapat dikembangkan oleh masyarakat, kondisi sosial ekonomi, budaya, pola pemanfaatan lahan pekarangan yang sudah dilaksanakan oleh masyarakat, teknologi tepat guna dalam budidaya di pekarangan untuk meningkatkan produktivitas, peluang pasar, SDM, keterampilan, pengetahuan dan sarana prasarana pendukung lainnya.

2. Penentuan peserta penyuluhan. Penentuan petani peserta kegiatan penyuluhan ini dilakukan oleh ketua kelompok tani sesuai saran dan persyaratan yang telah ditetentukan oleh Tim Pelaksana.

3. Penetapan waktu pelaksanaan kegiatan penyuluhan. Pelaksanaan penyuluhan disepakati dilaksanakan sekitar Agustus-September 2021.

4. Persiapan dan pengadaan bahan dan alat untuk kegiatan penyuluhan.

\section{Tahap Pelaksanaan}

Kegiatan penyuluhan dilakukan pada tanggal 4 September 2021 yang berlangsung sejak pukul 09.30 sampai pukul 12.15 di dusun Amor-Amor, Desa Gumantar. Jadual pelaksanaan penyuluhan mengalami penundaan dari rencana semula karena mempertimbangkan kondisi perkembangan covid19 di bulan Juli yang mengalami peningkatan.

Materi penyuluhan disampaikan secara langsung oleh Tim PPM yang diikuti diskusi/ tanya jawab terkait materi yang disampaikan dan permasalahan yang dialami masyarakat sasaran dalam pengelolaan lahan pekarangan, serta prinsip gizi seimbang dalam konsumsi pangan untuk hidup sehat. Penyampaian materi penyuluhan dilakukan melalui media dalam bentuk powerpoint yang ditanyangkan melalui LCD proyektor. Presentasi Power Point menampilkan secara visual penerapan berbagai teknologi tepat guna 
dalam budidaya tanaman hortikultura di lahan pekarangan. Materi penyuluhan meliputi berbagai inovasi teknologi tepat guna yang dapat diterapkan dalam pengelolaan pekarangan, di antaranya teknik bertanam model vertikultur, budidaya dalam wadah (polibag), teknik No Dig Plot, teknik budidaya hamparan, dan teknik budidaya berbagai komoditas tanaman hortikultura yang disesuaikan dengan kebutuhan masyarakat setempat dan pasar. Materi penyuluhan juga mencakup konsep dan pronsip gizi seimbang dalam konsumsi pangan sehar-hari untuk memenuhi kebutuhan gizi masyarakat, salah satunya dengan memanfaatkan bahan pangan hasil pekarangan.
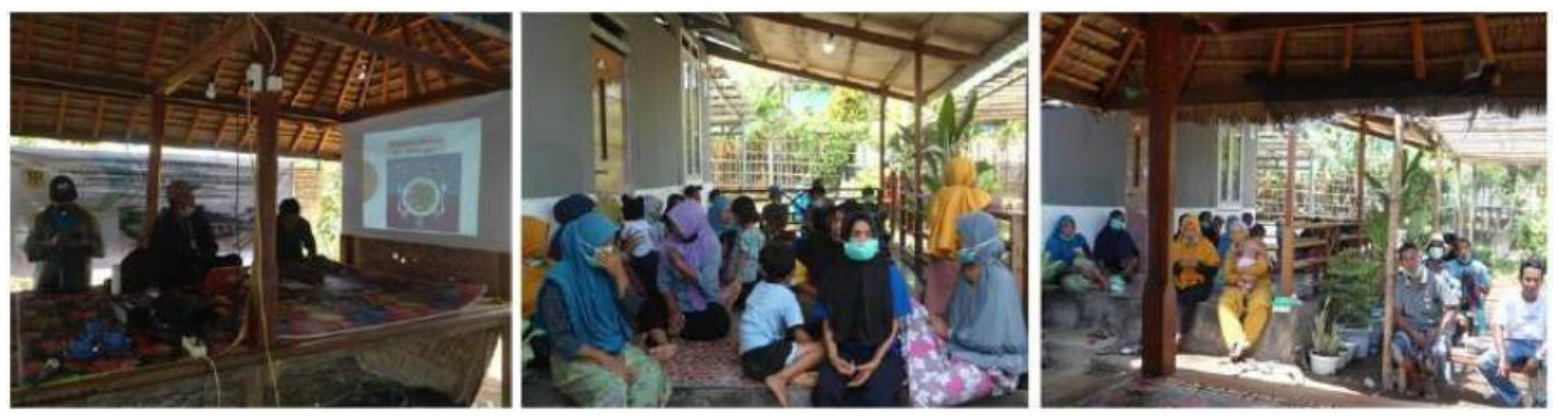

Gambar 1. Suasana kegiatan Penyuluhan Pemanfaatan Pekarangan Sebagai Sumber Pangan dan Gizi

Selama penyuluhan berlangsung, para peserta penyuluhan antusias menyampaikan beberapa pertanyaan. Berikut secara umum diskusi terkait pertanyaan para peserta. Bahwa dalam pengaturan pekarangan sebagai lahan budidaya komoditi sumber pangan dan gizi, maka desain pemanfaatan pekarangan dimaksud adalah penataan pertanaman, disesuaikan dengan luas dan strata lahan pekarangan. Penentuan jenis komoditas yang akan di tanam di halaman rumah, semua rumah tangga menentukan sendiri komoditi yang akan ditanam dan dikembangkan, tentunya disarankan tanpa melupakan komoditas lokal. Terkait pengolahan tanah tentunya dilakukan oleh pemilik pekarangan apakah berkenan menanam langsung dengan mempersiapkan bedengan-bedengan ataupun menanm dalam wadah (pot) ataupun polybag.

\section{Tahap Evaluasi}

Evaluasi merupakan kegiatan akhir program penyuluhan yang dilakukan terhadap peran dan keterlibatan peserta, antusiasme serta serapan peserta terhadap materi kegiatan penyuluhan. Menurut Amanah dan Farmayanti (2014), model penyuluhan dengan pelibatan masyarakat sejak awal perencanaan program atau penetapan prioritas isu dan permasalahan yang dihadapi di lapang, sehingga pelaksanaan dan evaluasi penyuluhan merupakan kegiatan yang perlu dilakukan agar penyuluhan dapat diketahui memberi manfaat bagi masyarakat sasaran. Dalam pelaksanaan kegiatan ini tidak mendapatkan hambatan yang berarti, para peserta pelatihan cukup memahami semua materi yang diberikan. Penyampaian materi yang dilakukan dengan bahasa yang sederhana dan lebih banyak menggunakan bahan peraga atau lebih banyak menunjukkan contoh-contoh kasus secara langsung sangat mendukung dan menambah pemahaman peserta.

Minat dan perhatian peserta dalam mengikuti kegiatan penyuluhan yang cukup tinggi merupakan faktor pendorong yang kuat dalam proses implementasi kegiatan pengabdian kepada masyarakat ini pada tahapan pelatihan dan pendampingan pemanfaatan pekarang secara nyata. Disamping itu adanya dukungan yang cukup kuat dari aparat desa terutama dari Kepala Desa dan Kepala Dusun, dan tokoh masyarakat memberikan andil yang cukup besar untuk keberhasilan kegiatan pengabdian kepada masayarakat ini. 
Dari hasil pengamatan selama berlangsungnya kegiatan penyuluhan dapat diutarakan beberapa hal sebagai berikut: a) respon peserta penyuluhan cukup tinggi (antusias), hal ini dapat dilihat dari keseriusan dan ketekunan seluruh peserta untuk mengikuti proses penyuluhan. Hal ini tentu dapat menjadi bekal tambahan pengetahuan bagi mereka terkait upaya realisasi optimalisasi lahan pekarangan untuk mendukung kemandirian pangan dan pemenuhan kebutuhan pangan dan gizi keluarga; dan b) materi yang disampaikan cukup relevan dengan kebutuhan peserta, dan mudah dimengerti oleh peserta, hal ini dapat dilihat dari diskusi dan pertanyaanpertanyaan yang diajukan oleh peserta cukup relevan dengan topik yang dibahas.

Respon peserta petani sasaran (kelompok Tani Lembah Telaga) sangat baik, dan para peserta sangat merasakan adanya peningkatan pengetahuan dan pemahaman dalam hal penyediaan sumber pangan melalui pengelolaan pekarangan dan pemahaman perlunya penganekaragaman dalam konsumsi pangan dengan prinsip gizi seimbang dalam menu makanan sehari hari untuk mencapai status gizi yang baik/ sehat. Mereka sangat berharap adanya pembinaan dan pendampingan dalam merealisasikan pengelolaan pekarangan lebih lanjut, oleh karena itu dukungan dari pemerintah setempat terutama dari aparat desa dan PPL sangat diperlukan untuk memfasilitasi penyelenggaraan tindak lanjut pertemuan dan pembinaan selanjutnya. Khususnya kami sebagai tim PPM, pun sangat mendukung untuk keberlanjutan program ini. Seperti dikatakan Marliati dkk, 2008) bahwa kegiatan tersebut yang menunjukkan keberhasilan awal dapat memberikan kontribusi kinerja penyuluh yang menjadi baik dan maksimal dalam upaya pemberian informasi bagi masyarakat.

Hasil wawancara yang dilakukan ditengah-tengah berlangsungnya diskusi setelah memberikan materi penyuluhan menunjukkan bahwa anggota Kelompok Tani Lembah Telaga membutuhkan informasi pertanian yang berkaitan dengan teknologi produksi atau teknik budidaya tanaman pada lahan pekarangan dan juga teknik bertanam dalam wadah (pot), hal ini disebabkan karena teknologi budidaya pertanian yang belum dikuasai oleh anggota Kelompok Tani tersebut. Informasi yang dibutuhkan oleh anggota Kelompok Tani adalah informasi yang berkaitan dengan cara melakukan penanaman yang baik dan benar, cara melakukan perawatan pada tanaman. Sirnawati et.al. (2015) mengutarakan bahwa keberhasilan pelaksanaan pengelolaan pekarangan yang apalagi sebagai Kawasan Rumah Pangan Lestari dipengaruhi oleh beberapa variabel, yaitu sumber benih, ketersediaan bibit, luas lahandan jumlah pekarangan, perencanaan rotasi tanam, sistem integrasi ternak/tanaman, konservasi sumberdaya pangan lokal, sistim pengelolaa, keterlibatan aparat/unsur Kabupaten/Kota, dan jejaring pemasaran.

Teknologi budidaya tanaman khususnya tanaman hortikultura dalam rangka optimalisasi pemanfaatan lahan pekarangan bagi masyarakat sasaran merupakan suatu hal yang dianggap sebagai inovasi atau teknologi baru. Sehingga melalui penyuluhan dan kemudian diikuti dengan pelatihan, serta demplot diharapkan bahwa inovasi dan teknologi ini mampu diadopsi oleh masyarakat sasaran guna mendukung kemandirian pangan rumah tangga dan pemenuhan kebutuhan pangan dan gizi.

\section{KESIMPULAN DAN SARAN}

Melalui penyuluhan ini, sebagai dorongan awal dari perubahan prilaku masyarakat dalam pengelolaan lahan pekarangan dengan berbagai komoditas tanaman hortikultura yang baik sebagai sumber pangan dan gizi sudah ada. Oleh karena itu, proses lanjutannya yakni realisasi pendampingan dalam mempersiapkan dan mengelola pekarangan dimaksud perlu disegerakan dilakukan.

Inovasi dan teknologi pemanfaatan pekarangan sebagai sumber pangan dan gizi keluarga bukan hanya teradopsi oleh peserta penyuluhan yang telah dilakukan ini, tetapi diharapkan mampu ditularkan dan disebarluaskan pada masyarakat yang berminat untuk mengembangkan. 


\section{DAFTAR PUSTAKA}

Amanah, S. dan N. Farmayanti. 2014. Pemberdayaan Sosial Petani-Nelayan, Keunikan Agroekosistem, dan Daya Saing. Jakarta: Yayasan Pustaka Obor Indonesia.

Ashari, Saptana, Purwantini TB. 2012. Potensi dan Prospek Pemanfaatan Lahan Pekarangan untuk Mendukung Ketahanan Pangan. Forum Penelitian Agro Ekonomi, 30 (1): 13 - 30.

Daniel, M., Darmawati dan Nieldalina. 2005. PRA: Participatory Rural Appraisal: Pendekatan Efektif Mendukung Penerapan Penyuluhan Partisipatif dalam Upaya Percepatan Pembangunan Pertanian. Penerbit PT Bumi Aksara. Jakarta.

Sirnawati, E., A. Yulianti, dan A. Ulpah. 2015. Faktor-Faktor Yang Mempengaruhi Keberhasilan Kawasan Rumah Pangan Lestari Di Pulau Sumatera. Jurnal Pengkajian dan Pengembangan Teknologi Pertanian 18(1):11-27

Kementan, 2011. Pedoman Umum Model Kawasan Rumah Pangan Lestari. Kementerian Pertanian. Jakarta

Kementan, 2012. Pengembangan Kawasan Rumah Pangan Lestari (KRPL). Kementerian Pertanian. Jakarta

Marliati, Sumardjo, P.S. Asngari, P. Tjitropranoto dan A. Saefuddin. 2008. Faktor-faktor Penentu Peningkatan Kinerja Penyuluh dalam Memberdayakan Petani. Penyuluhan. 4 (2): 92-93.

Rizal, M dan Fiana, Y. 2015.Teknologi Budidaya Tanaman Sayuran dan Toga di Perkotaan dan Pedesaan pada Kawasan Rumah Pangan Lestari dalam mendukung Ketahanan Pangan di Kalimantan Timur. Prosiding Seminar Nasional Masyarakat Biodiversitas Indonesia. Volume 1, Nomor 2, April 2015.

Widyawati, A. T. and Rizal, M. (2015). Potensi Pengembangan Tanaman Sayuran Skala Rumah Tangga di Samarinda, Kalimantan Timur. Prosiding Seminar Nasional Masyarakat Biodiversitas Indonesia. Volume 1, Nomor 2, April 2015. 